No. 21-14

\title{
Opting in with the Joneses: What Affects the Timing of Municipal Adoption of a Local-option Meals Tax?
}

\section{Bo Zhao}

\begin{abstract}
:
States use local-option taxes to promote local revenue diversification and improve local fiscal health. However, many sub-state governments wait a long time before adopting local-option taxes or do not adopt them at all, which seems puzzling or even irrational upon first glance. This paper uses the localoption meals tax in Massachusetts as a case study to examine the factors that affect the timing of local adoptions. It finds significant positive results for adoption by neighboring municipalities, which are robust to a variety of specifications, neighbor definitions, and weighting matrices. The adoption hazard also increases if a municipality faces greater fiscal stress, such as being more constrained by a property tax limitation or receiving a larger cut in state aid. In addition, the form of local government, size of the meals tax base, and ability to export the tax to non-residents are important factors.
\end{abstract}

JEL Classifications: C41, H71, H73, H77, R50

Keywords: local-option tax, yardstick competition, policy diffusion, fiscal stress, hazard model

Bo Zhao is a senior economist with the New England Public Policy Center in the Research Department of the Federal Reserve Bank of Boston. His email address is Bo.Zhao@bos.frb.org.

The author thanks Jeff Thompson and participants at the National Tax Association's annual conference, the Association for Budgeting and Financial Management's annual conference, and the Federal Reserve Bank of Boston Research Department's Brown Bag Seminar for helpful comments. Lan Ha, Eli Inkelas, and Calvin Kuo provided excellent research assistance.

The views expressed herein are those of the author and do not indicate concurrence by the Federal Reserve Bank of Boston, the principals of the Board of Governors, or the Federal Reserve System.

This paper, which may be revised, is available on the website of the Federal Reserve Bank of Boston at https://www.bostonfed.org/publications/research-department-working-paper.aspx. 


\section{Introduction}

Local-option taxes have become increasingly important for local governments in the United States over the recent decades. For the nation as a whole, local sales tax as a share of total local tax revenue grew from 13 percent in 1979 to nearly 18 percent in $2019 .{ }^{1}$ In 1979 , local sales tax accounted for 20 percent or more of total local tax revenue in nine states. By 2019, the number of such states had doubled to 18 .

States use local-option taxes to promote local revenue diversification and improve local fiscal health. Since the property tax revolt that started in the late 1970s, many states have authorized local-option taxes to reduce local reliance on property taxes. Local-option taxes are also a tool for local governments to deal with state aid losses. State governments experienced unprecedentedly large revenue shortfalls during and in the aftermath of the 2001 and 2007-2009 recessions. As a result, they implemented significant aid cuts, which could be partly offset by localoption taxes.

However, researchers, practitioners, and policymakers observe that there have been significant differences among local governments in the timing of adopting a local-option tax. Some localities have adopted the tax immediately once the state made it available. Others have waited longer, and some may never adopt it. Given the aforementioned benefits of local-option taxes, it seems puzzling or even irrational that some sub-state governments do not take advantage of new taxes immediately or at all. Therefore, it is important to investigate whether there is an explanation for this adoption behavior pattern. This helps shed light on the development of local tax structure, which is an understudied area, as previous research focuses on explaining existing fiscal structure. The investigation also helps improve the understanding of policy innovation and diffusion. In

\footnotetext{
${ }^{1}$ Source: U.S. Census Bureau's Annual Survey of State and Local Government Finances
} 
particular, it provides insight into the effect of neighboring jurisdiction' behavior on the process of adopting a new policy tool, beyond the traditional focus on the effect on the tax rate and base.

This paper uses the local-option meals tax in Massachusetts as a case study to examine the factors that affect the timing of local adoptions. It contributes to a small but growing literature that so far includes only five papers that study the factors influencing the duration of time between a state's authorization of a local-option tax and the adoption of this tax by a local government: Zhao (2005), Sjoquist et al. (2007),Burge and Piper (2012), Afonso (2018), and Chen and Afonso (2021). ${ }^{2}$ This paper expands on these studies to make several new contributions to the literature.

This is the first study to use data from outside the southern United States; existing papers use data from Georgia, Oklahoma, Texas, and Florida. Compared with these states, Massachusetts has a different institutional environment for local governments. First, Massachusetts has a flatter local government system: It essentially has no county governments, ${ }^{3}$ and throughout the state, school districts have no authority to raise taxes and are fiscally dependent on municipal governments. Local governments in Massachusetts also rely more heavily on property tax

\footnotetext{
${ }^{2}$ Three other papers are relevant, but in a less direct way. Luna, Bruce, and Hawkins (2007) conduct a survival analysis of the duration of time from Tennessee's authorization of a local-option sales tax until a county government reaches a legal sales tax rate maximum. Spry (2005) and Hall and Ross (2010) use a probit model and one-year data to examine the factors that affected Ohio school districts' likelihood of adopting a local-option income tax by January 1, 1997. Regarding the role of neighbors' influence, this paper is also related to the literature on local sales tax competition, which examines the strategic behavior of local governments in responding to neighbors' changes in statutory tax rates (for example, Agrawal 2014; Agrawal 2016; Burge and Rogers 2011; Burge and Rogers 2016; Gentry et al. 2020; and Luna 2004).

${ }^{3}$ Only 5 out of the 14 counties have county governments, but their functions are very limited. They include the operation of courthouses and jails and other correctional institutions, the registration of deeds, and the maintenance of regional hospitals and agricultural schools.
} 
compared with those in the South. ${ }^{4}$ It is therefore important to examine whether previous findings apply to a state in a different region with a different institutional context such as Massachusetts. ${ }^{5}$

While previous research investigates local-option sales and fuel taxes, this paper is the first to examine the adoption of a local-option meals tax. The tax base of the local-option meals tax differs from those of other taxes in the content, size, and spatial distribution, as well as sensitivity to tax increases and cross-border shopping. In addition, the local-option meals tax policy in Massachusetts has several features that differentiate it from the local-option sales and fuel tax policies in the aforementioned southern states. First, Massachusetts has a uniform rate for the localoption meals tax, unlike the southern states, which allow local governments to choose from a range of tax rates. Second, the adoption of the local-option meals tax in Massachusetts is determined by municipal legislative bodies, while local referendums are required in the southern states. Third, Massachusetts does not require the local meals tax revenue to be earmarked for specific purposes, whereas earmarking is often required in the southern states.

Expanding on previous research, this paper is the first to examine the roles of property tax limitation, state aid, form of local government, commuters, and population density. These factors can be conceptually linked to the adoption incentive and affect when the tax is adopted.

This paper also expands the robustness analysis of neighboring municipalities' influence. First, it tests three definitions of neighbors for each locality: localities sharing a common border, localities in the same county, and localities within 25 miles. Each of the five previous studies uses

\footnotetext{
${ }^{4}$ According to the 2019 Survey of State and Local Government Finances, 52 percent of local general revenue for Massachusetts was from property tax, compared with 22 percent, 27 percent, 30 percent, and 42 percent for Oklahoma, Georgia, Florida, and Texas, respectively.

${ }^{5}$ For example, the vertical tax competition between county and municipal governments is found to be an important consideration for Oklahoma municipalities (Burge and Piper 2012), but it is irrelevant for Massachusetts municipalities since the state essentially has no county governments.
} 
only one of these definitions. ${ }^{6}$ Second, this paper uses six weighting matrices in which neighbors are weighted by equal weight, population, meals tax base, inverse of the distance between a neighboring municipality and the home municipality, inverse-distance times population, and inverse-distance times meals tax base. Previous studies use three or fewer weighting matrices, and none considers the distance from a neighbor. ${ }^{7}$ Third, the models in previous studies do not account for the possibility that the home locality's decision and neighbors' behavior may be simultaneously driven by their common environment and therefore biases the neighbor variable upward. This paper addresses this concern by controlling for county fixed effects, since all or most of the neighboring municipalities as defined in this paper are located in the same county as the home municipality. Finally, while previous studies do not include a placebo test, I conduct an experiment in which cities and towns are arbitrarily assigned as neighbors to each municipality. The results of the placebo test provide additional support for the findings on neighbors' influence.

\section{Policy Background}

In mid-2009, the state legislature of Massachusetts approved a local-option meals tax as part of the Municipal Relief Act. During the Great Recession, the state experienced large budget gaps. To balance the budget, it significantly cut local aid, which led to revenue shortfalls for many cities and towns. Intended to provide fiscal relief, the new state law allowed municipalities to adopt the local-option meals tax as early as fiscal year 2010 .

\footnotetext{
${ }^{6}$ Zhao (2005), Burge and Piper (2012), and Chen and Afonso (2021) use the first definition to define a county's neighbors. Burge and Piper (2012) use the second definition to define a municipality's neighbors. Sjoquist et al. (2007) and Afonso (2018) use the third definition.

${ }^{7}$ Zhao (2005), Afonso (2018), and Chen and Afonso (2021) use only equal weights. Sjoquist et al. (2007) use both equal weights and sale-tax-base weights. Burge and Piper (2012) weigh counties' neighbors using equal weights and population weights and use equal weights and sales-tax-base weights for municipalities' neighbors.
} 
The design of this tax provides incentives for municipal adoption. An adopting municipality can apply the local-option meals tax to the same sales of meals as the state meals tax. Taxable meals include any food or beverage sold for immediate consumption by a restaurant or store, such as a supermarket or grocery store. The state law sets a uniform local-option meals tax rate at 0.75 percent, which eliminates the possibility of tax rate competition among adopters. As restaurant meals are also subject to the state meals tax at a 6.25 percent rate, the combined state and local tax rate is 7 percent in municipalities that have adopted the local-option meals tax. To minimize local administrative costs, the state collects local meals taxes on behalf of municipalities and returns them to those cities and towns. Municipal governments can use the revenue however they desire, since the state does not require it to be earmarked for any specific purpose. In addition, adopting the tax requires only a majority vote of the local legislative body (council or town meeting), not a local referendum.

Municipalities have differed in whether or when they have adopted the local-option meals tax. Adoption surged in the early period after the state's approval of the tax. That initial spike was followed by slower growth through the end of the decade. Seventy-two municipalities, or 21 percent of the 351 municipalities in Massachusetts, adopted the tax in the first year, FY2010 (Figure 1). The next two years saw 79 more adoptions. Since then, the growth in adoption has continued gradually. The total number of adoptions reached 219 in FY2017, the final year analyzed in this study due to data availability constraints for independent variables. By the end of FY2020, the total number of adopting municipalities stood at 241 .

\section{Empirical Model}


Without considering any covariates, Figure 2 shows that the smoothed hazard estimate for municipal adoption is not monotonic with time. The adoption hazard for a municipality that has not yet adopted the tax initially increases and then decreases over time.

I use a Cox Proportional-Hazards model, an often-used semi-parametric method, to study which covariates affect the adoption hazard and how they affect it. The model is simply expressed as

$$
h\left(t_{i}\right)=h_{0}(t) e^{\left(\beta X_{i}\right)},
$$

where $h\left(t_{i}\right)$ is the adoption hazard for municipality $i$ in year $t$ if this municipality had not adopted the tax by the previous year; $h_{0}(t)$ is the baseline hazard; and $X$ is a vector of covariates. A positive coefficient $\beta$ suggests that a covariate has a positive effect on the hazard. Furthermore, a one-unit increase in the covariate results in a change of $\left(e^{\beta}-1\right)$ in the hazard rate, which is positive if $\beta>0$ and negative if $\beta<0$.

The Cox Proportional-Hazards model makes no assumption about the baseline hazard. This is an advantage over the parametric methods used by Zhao (2005) and Sjoquist et al. (2007), which assume that the error term of the survivor function follows a certain distributional form. But as the above equation shows, this model assumes that the covariates have a multiplicative effect on the hazard function. Thus, each unit increase in a covariate results in proportional scaling of the hazard rate. I test this proportional-hazards assumption on the basis of Schoenfeld residuals and do not find that the assumption is violated. To minimize the potential endogeneity bias, I use the one-year lagged value of a covariate if the variable is time varying. Furthermore, I cluster standard errors by municipality to allow for a correlation of the error terms within municipalities. 
In the full specification, the covariates can be categorized into three groups. The first group includes independent variables that are hypothesized to affect the incentive for municipal adoption. I discuss them in detail in the next section. To minimize potential omitted-variable bias in estimating the effect of the first-group variables, I include the second and third groups of covariates

as controls. The second group contains an extensive set of socioeconomic and demographic characteristics of each municipality, including income level, age distribution, educational attainment, racial and ethnic composition, and political affiliation, as well as indicators of whether the municipality borders another state. The five previous studies include only some of these variables in their model. The third group includes county fixed effects.

\section{Hypotheses}

I hypothesize that five types of factors can be linked to municipal incentive to adopt the localoption meals tax. They are (1) neighbors' influence, (2) meals tax revenue potential, (3) ability to export meals tax liability to non-residents, (4) form of local legislative body, and (5) fiscal stress. I derive or develop these hypotheses based on previous studies, intuition, and anecdotal evidence.

\section{Neighbors' Influence}

Different theories make different predictions about the role of neighbors' influence. Traditional tax competition theory predicts that when more neighboring municipalities adopt the local-option meals tax, the home municipality will delay adoption in order to maintain its tax competitiveness. In doing so, it hopes to attract more restaurants and customers from neighboring cities and towns to its jurisdiction. However, the yardstick competition theory predicts that an increase in neighbors' adoption will lower the political cost to the home municipality of adopting the new tax and thus speed up its adoption. Voters in the home municipality use neighbors' financial condition, 
including tax structure, as a benchmark to evaluate the performance of their own government. They are more likely to support the adoption of the new tax as a sound policy if more neighboring municipalities have adopted it. In addition, the policy diffusion or technology transfer theory predicts that the home municipality will face a lower information cost of adopting the new tax and therefore shorten its wait for adoption when more neighboring municipalities have adopted it. More adoption by neighboring municipalities provides the home municipality with more opportunities to observe and learn from their experience with the new tax.

Previous research shows mixed results on neighbors' influence. Zhao (2005), Sjoquist et al. (2007), and Burge and Piper (2012) find that neighbors' adoption plays a positive role in the home locality's decision to adopt a local-option tax. However, Afonso (2018) and Chen and Afonso (2021) find that neighbors' adoption has a negative effect and no effect, respectively, on the home locality's adoption.

Anecdotal evidence in Massachusetts seems to be more consistent with the predictions of the yardstick competition theory and the policy diffusion or technology transfer theory. For example, the Massachusetts Municipal Association states, "Some communities warm to the idea of the local-option meals tax after it has been adopted by surrounding communities" ${ }^{\text {. }}$.

Figure 3 shows the temporal evolution and spatial evolution of municipal adoption, which also suggest a positive effect from neighbors. After the initial adoption by 72 municipalities in FY2010, a large number of municipalities surrounding these earliest adopters adopted the tax in

\footnotetext{
${ }^{8}$ See Massachusetts Municipal Association, "Nearly Half of Mass. Communities Have Adopted Local-option Meals Tax,” 2013.
} 
the next three years, resulting in spatial clusters. These clusters continued to snowball and covered almost the entire eastern portion of the state and the majority of central Massachusetts by FY2017.

In the empirical model, I use the one-year lagged value of the neighbors' adoption percentage to minimize the "reflection" problem. The reflection problem refers to a mechanical occurrence where the neighbors' outcome and the home municipality's decision could influence each other if both are measured in the same year. Because the home municipality is its neighbors' neighbor, its decision in year $t$ would be included in calculating the neighbors' outcome in year $t$ for each of the home municipality's neighbors and therefore could affect the home municipality's neighbors in that year. However, using the one-year lagged value of the neighbors' outcome can break the reflection, since the home municipality's decision in year $t$ cannot affect its neighbors' outcome in year $t-1$. In contrast, previous studies use the contemporaneous value of the neighbor variable, except for Burge and Piper (2012), which includes both the contemporaneous and oneyear lagged value.

There is also a plausible economic reason for using the one-year lagged value of neighbors' adoptions. Voters and the legislative body of a given municipality may prefer to observe and learn from a full year or longer of a neighbor's experience with the new tax before making their decisions. Therefore, neighbors' adoptions in year $t-1$ and earlier may actually matter more in the home municipality's decision-making in year $t$.

To test the robustness of the results to different neighbor definitions, I use three levels of spatial proximity to the home municipality to define neighbors. First, I define neighbors as adjacent municipalities that share a common border with the home municipality. The median number of adjacent neighbors is five. Second, I define neighbors to be municipalities that are located in the same county as the home municipality. There are 14 counties in Massachusetts. The median 
number of county-based neighbors is 31 . Finally, I define neighbors as municipalities whose centroids are within 25 miles of the centroid of the home municipality. This definition results in the largest neighbor set among the three definitions, with the median number of neighbors being 61.

Because they are spatially close to each other, a municipality and its neighbors likely share a common environment. It is possible that the environment simultaneously drives the behavior of the home municipality and its neighbors. Neighbors' outcomes may capture the role of the common environment; if so, their effect on the home municipality's decision could be overestimated. To reduce this potential omitted-variable bias, I include county fixed effects as additional controls in the full specification. The rationale is that all or most of the neighboring municipalities as defined in this paper are located in the same county as the home municipality. Therefore, county fixed effects help control for the common environment that the home municipality and its neighbors share.

Once each municipality's neighbors are determined, there are the questions of whether to treat them equally and how to weigh them. When neighbors are defined based on the centroid-tocentroid distance, I use six weighting matrices to weigh each of these neighbors as a robustness check. The weights include (1) equal weight, (2) population, (3) meals tax base, (4) inverse of distance from home municipality's centroid to neighbor's centroid, (5) population times inverse of distance, and (6) meals tax base times inverse of distance. When neighbors are narrowly defined as municipalities adjacent to the home municipality, I use only the first three weighting matrices. Given that neighbors in this case border the home municipality, it would be unnecessary and excessive to consider distance in weighing these neighbors. When neighbors are defined as being located in the same county, I use only the last three weighting matrices. Using the first three 
weighting matrices results in little variation in the neighbor-adoption variable within counties, because two municipalities in the same county have the same neighbors, except that they have each other as neighbor. Therefore, the neighbor-adoption variable using any of the first three weighting matrices has almost the same value for municipalities within the same county. But using the inverse of distance as a weight introduces variation in the neighbor variable among municipalities within the same county and helps to identify the variable in the full specification with county fixed effects.

\section{Meals Tax Revenue Potential}

A municipality has a stronger incentive to adopt the local-option meals tax if it can raise more revenue from this tax. ${ }^{9}$ Meals tax revenue potential is proportional to meals tax base, given the uniform tax rate. Therefore, I hypothesize that a higher per capita meals tax base increases the hazard rate for municipal adoption of the local-option meals tax.

Data on meals tax base are obtained from the Massachusetts Department of Revenue (DOR). The DOR uses state meals tax collections in each municipality to back out local meals tax revenue for each municipality (realized revenue for adopters and potential revenue for nonadopters), since the state and local tax applies to the same tax base but at different rates. To avoid potential reverse causality between the meals tax base and municipal adoption of the local-option meals tax, I use the one-year lagged value of meals tax base. ${ }^{10}$

\footnotetext{
${ }^{9}$ A local newspaper in Massachusetts reported in 2014 that "'economic centers where there are a lot of restaurants have gotten some significant revenue,' said John Robertson, legislative director for the Massachusetts Municipal Association...Many towns that have not adopted the tax, Robertson said, have few restaurants and wouldn't see a huge revenue boost." See Gerry Tuoti and Marc Larocque, "Meals Tax Has Generated \$357M in State Revenue," Taunton Daily Gazette, August 31, 2014.

${ }^{10}$ There are reasons to expect that the local-option meals tax has little impact on the meals tax base. First, the local meals tax is often not salient to customers because restaurants tend to combine state and local meals tax into one item simply labeled as "tax" on restaurant bills. Second, a local meals tax at the 0.75 percent rate results in only a 0.70 percent increase in the after-tax price, which is a negligible change for many customers. Third, demand for restaurant
} 


\section{Tax Exportation}

A municipality is more likely to adopt the local-option meals tax if it can export a greater share of the tax liability to non-residents. The tax will be more popular among residents if they pay a lower share of the tax liability but still benefit from greater local government spending supported by the new tax. I use three variables to approximate a municipality's ability to export the local-option meals tax liability to commuters, tourists, and other visitors. ${ }^{11}$ They are (1) net commuter inflow per 100 residents, (2) whether an interstate highway passes through the municipality, and (3) retail employment per 100 residents. ${ }^{12}$ Because commuters often purchase their meals near where they work, municipalities with greater commuter inflow can export more tax burden to those commuters. It is easier for municipalities with an interstate highway to attract non-resident visitors (especially from out of state) due to increased accessibility. Municipalities with more tourists tend to have a larger retail industry and therefore more retail employees.

\section{Form of Local Legislative Body}

A municipality's legislative body is responsible for the decision to adopt the local-option meals tax. Thus, the form of the local legislative body plays a role in whether and when to adopt the tax. There are three forms of local legislative body in Massachusetts: elected council, representative town meeting, and open town meeting. In an elected council or a representative town meeting, voters elect a limited number of people to represent them, while in an open town meeting, all voters can attend, debate, and vote. As a result, open town meetings can be much larger than councils or

meals is relatively inelastic. Reed, Levedahl, and Hallahan (2005) estimates that price elasticity of demand for food away from home is 0.69 .

${ }^{11}$ The Massachusetts Municipal Association notes, "The meals tax has also been popular in communities that attract tourists." See Massachusetts Municipal Association, "Nearly Half of Mass. Communities Have Adopted Local-option Meals Tax," 2013.

${ }^{12}$ I cannot use leisure and hospitality employment because the data are missing for many small municipalities. 
representative town meetings. Their members are less likely to be knowledgeable on issues brought before meetings, and their decision-making tends to be more cumbersome. Therefore, the hazard rate for adopting the local-option meals tax is likely to be higher for municipalities with an elected council or representative town meeting than for municipalities with an open town meeting.

\section{Fiscal Stress}

Greater fiscal stress can provide municipalities with a stronger incentive to adopt the local-option meals tax. The new tax revenue could help municipalities to balance the budgets. Fiscal stress can come from both the spending side and the revenue side of municipal budgets.

On the spending side, a municipality is likely to face greater fiscal stress if, due to certain socioeconomic characteristics, it has higher "uncontrollable costs" for providing the same level of local services (Bradbury and Zhao 2009). These socioeconomic characteristics are called cost factors and are outside the direct control of local officials at any given point in time. Many studies identify population density as a robust cost factor (for example, Bradbury and Zhao 2009 and Zhao 2018). Higher population density is associated with greater fire hazard and higher crime rate, driving up local spending. I hypothesize that a municipality with higher population density is more likely to experience cost-related fiscal stress and hence more likely to adopt the local-option meals tax.

On the revenue side, a municipality can experience fiscal stress from property tax and state grants- the two largest revenue sources. ${ }^{13}$ A municipality with a larger property tax base has

\footnotetext{
${ }^{13}$ Federal revenues are substantially smaller and less important than property taxes and state grants. In addition, data on federal revenues are missing for many municipalities.
} 
greater revenue-raising capacity from property tax. Therefore, it is likely to face less fiscal stress and have a weaker incentive to adopt the local-option meals tax.

How much property tax a municipality in Massachusetts can levy is also constrained by a property tax limitation called Proposition $2 \frac{1}{2}$. It prohibits property tax revenue from exceeding a levy ceiling and a levy limit. The levy ceiling is defined as 2.5 percent of total taxable property values. The levy limit is the maximum amount of property tax a municipality can levy in a given year. Its growth is limited to an automatic 2.5 percent a year unless there is a successful referendum to override the levy limit or there is new growth in the tax base that is not the result of revaluation. The levy limit must always remain below the levy ceiling and thus is more effective in constraining property tax revenue. In fact, the levy ceiling has grown so much higher than the levy limit as a result of housing price appreciation that it has essentially been non-binding in recent decades.

To help local officials understand how much their municipalities' levies are constrained by their levy limits, the state's DOR calculates the difference between the levy limit and the actual levy. This is known as the excess levy capacity, which represents the additional amount of property tax that a municipality can, but chooses not to, levy in a given year. The excess levy capacity can be considered a form of fiscal slack. A municipality with greater excess levy capacity is likely to face less fiscal stress and have less need to adopt the local-option meals tax to generate new revenue. ${ }^{14}$ In addition, the DOR calculates an accompanying measure called the override capacity. This is the difference between the levy ceiling and the levy limit, representing the maximum amount of revenue by which a municipality can override its levy limit. I include override capacity

\footnotetext{
14 A local Massachusetts newspaper quoted the assistant director of policy and research at the Massachusetts Taxpayers Foundation as saying that "if a city or town is bumping against property tax limits, it's [the local-option meals tax] an important source of additional revenue to them." See Gerry Tuoti and Marc Larocque, "Meals Tax Has Generated \$357M in State Revenue," Taunton Daily Gazette, August 31, 2014.
} 
in the model, but I do not expect it to affect the adoption hazard given the non-binding role of the levy ceiling.

Another source of fiscal stress is a reduction in state grants. During and in the aftermath of the Great Recession, the state made deep cuts to local aid, which forced many municipalities to trim spending and seek additional revenue in order to balance their budgets. Therefore, a municipality is likely to have a higher hazard for adopting the local-option meals tax if it experiences a larger decrease in per capita state grants. ${ }^{15}$

Existing studies produce mixed evidence on the role of fiscal stress in the adoption of localoption taxes. Proxy variables for fiscal stress are significant in Sjoquist et al. (2007) and Burge and Piper (2012), but not in Zhao (2005). Chen and Afonso (2021) find what they call "minimal evidence," given that proxy variables for fiscal stress are significant in only one of their four specifications.

\section{Results}

Table 1 tests the robustness of the results to different regression specifications, while the neighbor definition and the weighting matrix are held constant. In this table, neighbors are defined as municipalities whose centroids are within 25 miles of the centroid of the home municipality. They are given an equal weight when I calculate the neighbors' adoption percentage. The first regression specification includes only the variables that I hypothesize may affect the incentive to adopt the local-option meals tax. The second specification adds extensive socioeconomic and demographic controls, which might also influence the adoption decision but are correlated with the variables in

\footnotetext{
${ }^{15}$ The Massachusetts Municipal Association notes, "The additional municipal revenue [from the local-option meals tax] has helped cities and towns to balance budgets and continue providing services as they have grappled with local aid cuts." See Massachusetts Municipal Association, "Nearly Half of Mass. Communities Have Adopted Local-option Meals Tax," 2013.
} 
the first specification. The third specification adds county fixed effects, which are intended to control for the common external environment that might simultaneously drive neighbors' adoption and the home municipality's decision. The results are robust to these additional controls. In the remainder of the paper, I focus on the results from the third specification.

The hazard rate is estimated to increase along with the per capita meals tax base and the three tax exportation variables. ${ }^{16}$ This supports the hypothesis that municipalities are more likely to adopt the local-option meals tax if they can collect more revenue from it or shift a larger share of the meals tax liability to non-residents. Relative to municipalities with an open town meeting, municipalities with a representative town meeting are found to have a higher hazard rate for adopting the local-option meals tax. This is consistent with their facing a lower barrier to pass a vote for adopting the new tax.

Furthermore, Table 1 shows strong evidence that fiscal stress plays an important role in the decision to adopt the local-option meals tax. ${ }^{17}$ Municipalities with a higher population density or a larger percentage cut in per capita state grants are likely to face greater fiscal stress and, as expected, they are found to have a higher hazard rate for adopting the local-option meals tax. ${ }^{18}$ In contrast, municipalities with a larger per capita property tax base or greater excess levy capacity as a percentage of the maximum levy limit have a lower hazard rate for adopting the local-option

\footnotetext{
${ }^{16}$ I use the commuter data from the American Community Survey (ACS) 5-year estimates for 2011 through 2015. I also tried the commuter data from the ACS 5-year estimates for 2009 through 2013 (the only other commuter data within the sample period of this paper). The results are similar, regardless of which commuter data I use. In addition, I tried gross commuter inflow without deducting the commuter outflow. The results are almost the same as using the net commuter inflow.

${ }^{17}$ I also tested municipal total outstanding debt per capita as a fiscal stress variable, but it was not significant in the hazard model. I could not test the effect of stabilization fund balances and certified free cash on the adoption hazard because they have missing values for many municipalities.

${ }^{18}$ I also tried other potential cost factors including poverty rate, unemployment rate, year-over-year population change, and three-year population change. None of them was significant in the hazard model.
} 
meals tax. ${ }^{19}$ Such municipalities are likely to have greater ability to raise property tax revenue to balance the budgets.

The estimated coefficient on the neighbors' adoption percentage is positive and significant, which suggests that neighbors play a positive role in the home municipality's adoption. Converting the coefficient into a hazard ratio reveals that a 1 percentage point increase in the neighbors' adoption percentage, on average, results in a 1.6 percent increase in the hazard rate for the home municipality's adoption.

Table 2 tests the robustness of the estimated coefficient on the neighbors' adoption percentage to alternative neighbor definitions and weighting matrices, while the regression specification is held constant (that is, the third specification in Table 1). Since the coefficients on other variables are essentially unaffected by the change in the neighbor definition and the weighting matrix, they are omitted from this table to simplify the presentation. When neighbors are limited to adjacent municipalities, the neighbor-adoption variable is highly significant across all three weighting matrices. ${ }^{20}$ When neighbors are defined as municipalities in the same county or municipalities within a 25 -mile radius of the home municipality, the neighbor-adoption variable is significant only when unweighted or weighted solely by inverse distance.

Under these broader neighbor definitions, the neighbor-adoption variable loses significance when weighted by population and meals tax base due to reduced variation both across

\footnotetext{
${ }^{19}$ I tried the effective property tax rate, which is calculated as total property tax levy divided by total assessed property values. This variable was not significant in the hazard model. In addition, I tried including a dummy variable for successful overrides in the previous year, but it was not significant in the model.

${ }^{20}$ The three coefficients are not directly comparable because the neighbor-adoption variable has different meanings under different weighting matrices. When each neighbor is given an equal weight, the neighbor-adoption variable represents the percentage of neighbors that have adopted the tax. However, the population-weighted variable represents the percentage of all neighbors' populations that live in municipalities that have adopted the tax. The mealstax-base-weighted variable represents the percentage of all neighbors' meals tax bases that are subject to the localoption meals tax.
} 
and within municipalities. The weighting matrices place heavy importance on the behavior of cities with large populations and large meals tax bases, and these large cities tended to be early adopters of the local-option meals tax. This results in consistently high values of the neighbor-adoption variable during the entire analysis period for municipalities neighboring a large city. Using broader neighbor definitions amplifies this effect, since more municipalities have large cities as neighbors and therefore have high values for the weighted neighbor-adoption percentage. This produces less variation both across and within municipalities, weakening the predictive power of the neighboradoption variables.

As an additional robustness check, I conduct a placebo test for the neighbors' influence. I arbitrarily assign each municipality neighboring cities and towns, which are the neighbors of the next municipality alphabetically. For example, Abington is given Acton's neighbors. Because these neighbors are assigned arbitrarily and have no spatial relationship with the home municipality, there is no reason that their behavior should affect the home municipality. Table 3 shows that, as expected, adoption by arbitrarily assigned neighbors is irrelevant to the home municipality's hazard for adopting the local-option meals tax. This finding indicates that the significant results on neighbors' adoption in Tables 1 and 2 are indeed evidence of a spatial dependency between municipalities and not the results of some spurious process.

\section{Conclusion}

This paper explores the factors that affect the timing of municipal adoption of a local-option meals tax in Massachusetts. It finds significant positive results on neighboring municipalities' adoption, which are robust to a variety of specifications, neighbor definitions, and weighting matrices. Fiscal stress is also a strong motivator. In particular, the adoption hazard increases if a municipality faces a greater constraint of the property tax limitation or a larger cut in state aid. The form of local 
government also plays a role, since local legislative bodies are responsible for the adoption decision in Massachusetts. In addition, a municipality is likely to adopt the tax sooner if it can raise a larger amount of revenue from the tax or export a larger tax burden to commuters, tourists, and other non-residents.

The results of this paper expand on previous related findings by testing hypotheses in a different region and institutional context for a different tax. It further illuminates the role of fiscal stress and neighboring municipalities' behavior, on which previous research finds mixed evidence.

This work can also be beneficial to policymakers, particularly those in other New England states that have a similar institutional context as Massachusetts. In recent years, Maine and Connecticut have explored enacting a local-option meals tax. ${ }^{21}$ The results of this paper may help policymakers improve the design, execution, and evaluation of local-option tax policies. If states want to speed up the adoption process, they might consider regularly publishing information that this paper shows affects the adoption speed but is not readily available to local officials and the public. For example, they could release information on neighbors' adoption and the size of the local tax base on an annual basis. In cases where, as in Massachusetts, local legislative bodies are responsible for the adoption decision, states might consider providing such information directly to local legislators through either written materials or in-person informational sessions. Perhaps more important, states might want to consider whether they should even enact a local-option tax or instead choose a different policy option, given the potentially slow and uneven adoption process. This paper shows that municipalities facing greater fiscal stress are likely to adopt local-option taxes earlier. As a result, their tax competitiveness becomes worse relative to non-adopters, which

\footnotetext{
${ }^{21}$ See Steve Mistler, "Maine House Gives Early Approval to Local-option Meals and Lodging Tax," Maine Public, June 12, 2019; and Matt Pilon and Gregory Seay, "Solution: Alternative Revenue Sources Could Bolster City Budget, Lower Mill Rate," Hartford Business Journal, July 8, 2019.
} 
may be an undesirable outcome for state governments. States could instead make the immediate adoption of a new local tax mandatory or increase state taxes and then distribute the additional revenues through equalization formulas to localities. However, pursuing these alternative policy options could be politically more difficult than authorizing local-option taxes. 


\section{References}

Afonso, Whitney. 2018. "Time to Adoption of Local Option Sales Taxes: An Examination of Texas Municipalities." Public Finance Review 46(4): 558-582.

Agrawal, David R. 2014. "LOST in America: Evidence on Local Sales Taxes from National Panel Data." Regional Science and Urban Economics 49: 147-163.

Agrawal, David R. 2016. "Local Fiscal Competition: An Application to Sales Taxation with Multiple Federations.” Journal of Urban Economics 91: 122-138.

Bradbury, Katharine, and Bo Zhao. 2009. "Measuring Non-school Fiscal Disparities among Municipalities." National Tax Journal 62(1): 25-56.

Burge, Gregory S., and Brian Piper. 2012. "Strategic Fiscal Interdependence: County and Municipal Adoptions of Local Sales Taxes.” National Tax Journal 65(2): 387-416.

Burge, Gregory S., and Cynthia Rogers. 2011. "Local Option Sales Taxes and Consumer Spending Patterns: Fiscal Interdependence under Multi-tiered Local Taxation." Regional Science and Urban Economics 41: 46-58.

Burge, Gregory S., and Cynthia Rogers. 2016. "Leaders, Followers, and Asymmetric Local Tax Policy Diffusion." Journal of Regional Science 56(2): 313-331.

Chen, Can, and Afonso, Whitney B. 2021. "The Adoption of Local Option Fuel Taxes: Evidence from Florida Counties." Public Budgeting \& Finance 41(1): 51-75.

Gentry, Melissa, Nadia Greenhalgh-Stanley, Shawn M. Rohlin, and Jeffrey P. Thompson. 2020. "Dynamic Sales Tax Competition: Evidence from Panel Data at the Border." Federal Reserve Bank of Boston working papers series No. 20-5.

Hall, Joshua C., and Justin M. Ross. 2010. “Tiebout Competition, Yardstick Competition, and Tax Instrument Choice: Evidence from Ohio School Districts." Public Finance Review 38(6): 710737.

Luna, LeAnn. 2004. "Local Sales Tax Competition and the Effect on County Governments' Tax Rates and Tax Bases." Journal of the American Taxation Association 26(1): 43-61.

Luna, LeAnn, Donald J. Bruce, and Richard R. Hawkins. 2007. "Maxing Out: An Analysis of Local Option Sales Tax Rate Increases.” National Tax Journal 60(1): 45-63.

Reed, Albert J., J. William Levedahl, and Charles Hallahan. 2005. "The Generalized Composite Commodity Theorem and Food Demand Estimation." American Journal of Agriculture Economics 87(1): 28-37. 
Sjoquist, David L., William J. Smith, Mary Beth Walker, and Sally Wallace.2007. "An Analysis of the Time to Adoption of Local Sales Taxes: A Duration Model Approach." Public Budgeting \& Finance 27(1): 20-40.

Spry, John Arthur. 2005. "The Effects of Fiscal Competition on Local Property and Income Tax Reliance.” Topics in Economic Analysis \& Policy 5(1): 1-19.

Zhao, Zhirong. 2005. "Motivations, Obstacles, and Resources: The Adoption of the GeneralPurpose Local Option Sales Tax in Georgia Counties.” Public Finance Review 33(6): 721-746.

Zhao, Bo. 2018. "From Urban Core to Wealthy Towns: Nonschool Fiscal Disparities across Municipalities." Public Finance Review 46(3): 421-453. 
Table 1. Estimated Coefficients from Cox Proportional-Hazards Model for Municipal Adoption of Local-option Meals Tax

\begin{tabular}{|c|c|c|c|}
\hline & $(1)$ & $\overline{(2)}$ & $\overline{(3)}$ \\
\hline Neighbors' adoption percentage $^{\dagger}$ & $\begin{array}{l}0.0148^{* *} \\
(0.00594)\end{array}$ & $\begin{array}{l}0.0170^{* *} \\
(0.00666)\end{array}$ & $\begin{array}{c}0.0156^{*} \\
(0.00806)\end{array}$ \\
\hline Meals tax base per capita (thousands of 2010 dollars) ${ }^{\dagger}$ & $\begin{array}{c}0.114^{* * *} \\
(0.0337)\end{array}$ & $\begin{array}{c}0.0900^{* *} \\
(0.0376)\end{array}$ & $\begin{array}{l}0.143^{* *} \\
(0.0580)\end{array}$ \\
\hline \multicolumn{4}{|l|}{ Tax Exportation } \\
\hline Net commuter inflow per 100 residents & $\begin{array}{c}0.0106^{* * *} \\
(0.00343)\end{array}$ & $\begin{array}{c}0.00994^{* * *} \\
(0.00371)\end{array}$ & $\begin{array}{l}0.00661^{*} \\
(0.00402)\end{array}$ \\
\hline Dummy for interstate highway & $\begin{array}{c}0.289^{* *} \\
(0.133)\end{array}$ & $\begin{array}{c}0.300^{* *} \\
(0.140)\end{array}$ & $\begin{array}{c}0.390^{* * *} \\
(0.149)\end{array}$ \\
\hline Retail employment per 100 residents $^{\dagger}$ & $\begin{array}{c}0.0434^{* * *} \\
(0.0131)\end{array}$ & $\begin{array}{c}0.0499^{* * *} \\
(0.0133)\end{array}$ & $\begin{array}{c}0.0477^{* * *} \\
(0.0131)\end{array}$ \\
\hline \multicolumn{4}{|l|}{ Form of Local Legislative Body } \\
\hline Dummy for council & $\begin{array}{c}0.457^{* *} \\
(0.204)\end{array}$ & $\begin{array}{c}0.367 \\
(0.229)\end{array}$ & $\begin{array}{c}0.341 \\
(0.236)\end{array}$ \\
\hline Dummy for representative town meeting & $\begin{array}{c}0.549^{* * * *} \\
(0.201)\end{array}$ & $\begin{array}{c}0.466^{* *} \\
(0.205)\end{array}$ & $\begin{array}{c}0.432^{* *} \\
(0.188)\end{array}$ \\
\hline \multicolumn{4}{|l|}{ Fiscal Stress } \\
\hline Population density (thousands of people per square mile) ${ }^{\dagger}$ & $\begin{array}{c}0.116^{* * *} \\
(0.0210)\end{array}$ & $\begin{array}{c}0.108^{* * *} \\
(0.0296)\end{array}$ & $\begin{array}{c}0.0786^{* *} \\
(0.0369)\end{array}$ \\
\hline Total assessed property values per capita (thousands of 2010 dollars) ${ }^{\dagger}$ & $\begin{array}{l}-0.00132^{*} \\
(0.000704)\end{array}$ & $\begin{array}{l}-0.00145^{*} \\
(0.000847)\end{array}$ & $\begin{array}{c}-0.00460^{* *} \\
(0.00213)\end{array}$ \\
\hline Excess levy capacity as percent of maximum levy limit ${ }^{\dagger}$ & $\begin{array}{c}-0.0635^{* * *} \\
(0.0216)\end{array}$ & $\begin{array}{c}-0.0658^{* * *} \\
(0.0211)\end{array}$ & $\begin{array}{c}-0.0628^{* * *} \\
(0.0211)\end{array}$ \\
\hline Override capacity as percent of levy ceiling ${ }^{\dagger}$ & $\begin{array}{c}0.0107 \\
(0.00650)\end{array}$ & $\begin{array}{c}0.00961 \\
(0.00699)\end{array}$ & $\begin{array}{c}0.00843 \\
(0.00839)\end{array}$ \\
\hline Percent change in real per capita state grants ${ }^{\dagger}$ & $\begin{array}{c}-0.0145^{* *} \\
(0.00684)\end{array}$ & $\begin{array}{l}-0.0137^{* *} \\
(0.00690)\end{array}$ & $\begin{array}{l}-0.0113^{*} \\
(0.00656)\end{array}$ \\
\hline \multicolumn{4}{|l|}{ Socioeconomic and Demographic Controls } \\
\hline Median household income (thousands of 2010 dollars) $^{\dagger}$ & & $\begin{array}{c}-0.0115^{*} \\
(0.00628)\end{array}$ & $\begin{array}{l}-0.0121^{*} \\
(0.00719)\end{array}$ \\
\hline Percent of population aged 65 and over ${ }^{\dagger}$ & & $\begin{array}{r}-0.00307 \\
(0.0188)\end{array}$ & $\begin{array}{c}0.0139 \\
(0.0214)\end{array}$ \\
\hline Percent of population under age $18^{\dagger}$ & & $\begin{array}{c}0.0269 \\
(0.0217)\end{array}$ & $\begin{array}{l}0.00971 \\
(0.0243)\end{array}$ \\
\hline Percent of adults with Bachelor's degree or higher ${ }^{\dagger}$ & & $\begin{array}{c}0.0143 \\
(0.00891)\end{array}$ & $\begin{array}{l}0.0203^{* *} \\
(0.00972)\end{array}$ \\
\hline Percent of adults with less than high school diploma ${ }^{\dagger}$ & & $\begin{array}{l}0.00884 \\
(0.0192)\end{array}$ & $\begin{array}{c}-0.00270 \\
(0.0226)\end{array}$ \\
\hline Percent Black ${ }^{\dagger}$ & & $\begin{array}{r}-0.00685 \\
(0.0123)\end{array}$ & $\begin{array}{r}-0.00315 \\
(0.0128)\end{array}$ \\
\hline Percent Hispanic ${ }^{\dagger}$ & & $\begin{array}{c}-0.0198^{* *} \\
(0.00919)\end{array}$ & $\begin{array}{l}-0.00167 \\
(0.0118)\end{array}$ \\
\hline Percent registered republican voters ${ }^{\dagger}$ & & $\begin{array}{c}0.0106 \\
(0.0263)\end{array}$ & $\begin{array}{c}0.0240 \\
(0.0328)\end{array}$ \\
\hline Percent registered democratic voters ${ }^{\dagger}$ & & $\begin{array}{c}0.0184 \\
(0.0155)\end{array}$ & $\begin{array}{c}0.0141 \\
(0.0160)\end{array}$ \\
\hline Dummy for bordering CT & & $\begin{array}{c}-0.0448 \\
(0.430)\end{array}$ & $\begin{array}{c}0.285 \\
(0.493)\end{array}$ \\
\hline Dummy for bordering $\mathrm{NH}$ & & $\begin{array}{c}0.153 \\
(0.260)\end{array}$ & $\begin{array}{c}0.121 \\
(0.288)\end{array}$ \\
\hline Dummy for bordering NY & & $\begin{array}{l}-0.292 \\
(0.746)\end{array}$ & $\begin{array}{l}-0.409 \\
(0.725)\end{array}$ \\
\hline Dummy for bordering RI & & $\begin{array}{r}-0.0770 \\
(0.348)\end{array}$ & $\begin{array}{l}-0.352 \\
(0.420)\end{array}$ \\
\hline Dummy for bordering VT & & $\begin{array}{c}0.234 \\
(0.552)\end{array}$ & $\begin{array}{c}0.483 \\
(0.630)\end{array}$ \\
\hline County Fixed Effects & No & No & Yes \\
\hline
\end{tabular}

Source: Author's calculations.

Notes: ${ }^{*} p<0.10,{ }^{* *} p<0.05,{ }^{* * *} p<.01$.

Standard errors (in parentheses) are clustered at the municipality level.

$\dagger$ : variable is on a 1-year lag

$\S$ : reference category is open town meeting

Neighbors are defined as municipalities whose centroids are within 25 miles of the centroid of the home municipality. Neighbors are weighted equally in calculating neighbors' adoption percentage. 
Table 2. Estimated Coefficients on Neighbors' Adoption Percentage

\begin{tabular}{|c|c|c|c|}
\hline \multirow[b]{2}{*}{ Neighbors weighted by } & \multicolumn{3}{|c|}{ Neighbor definition } \\
\hline & Adjacent municipalities & Municipalities in same county & Municipalities within 25-mile radius \\
\hline Equal weight & $\begin{array}{c}0.0134^{* * *} \\
(0.00317)\end{array}$ & & $\begin{array}{c}0.0156^{*} \\
(0.00806)\end{array}$ \\
\hline Population & $\begin{array}{c}0.00914^{* * *} \\
(0.00262)\end{array}$ & & $\begin{array}{c}0.00164 \\
(0.00657)\end{array}$ \\
\hline Meals tax base & $\begin{array}{c}0.00683^{* * *} \\
(0.00242)\end{array}$ & & $\begin{array}{l}-0.00117 \\
(0.00537)\end{array}$ \\
\hline$\frac{1}{\text { Distance }}$ & & $\begin{array}{l}0.00989^{*} \\
(0.00519)\end{array}$ & $\begin{array}{l}0.0192^{* * *} \\
(0.00695)\end{array}$ \\
\hline$\frac{\text { Population }}{\text { Distance }}$ & & $\begin{array}{c}0.00632 \\
(0.00509)\end{array}$ & $\begin{array}{c}0.00840 \\
(0.00642)\end{array}$ \\
\hline$\frac{\text { Meals tax base }}{\text { Distance }}$ & & $\begin{array}{c}0.00407 \\
(0.00484)\end{array}$ & $\begin{array}{c}0.00284 \\
(0.00544)\end{array}$ \\
\hline
\end{tabular}

Source: Author's calculations.

Notes: ${ }^{*} p<0.10,{ }^{* *} p<0.05,{ }^{* * *} p<.01$.

Standard errors (in parentheses) are clustered at the municipality level.

Coefficients are estimated using the full specification (county fixed effects included). 
Table 3. Estimated Coefficients on Neighbors' Adoption Percentage in the Placebo Test

\begin{tabular}{|c|c|c|c|}
\hline \multirow[b]{2}{*}{ Neighbors weighted by } & \multicolumn{3}{|c|}{ Neighbor definition } \\
\hline & Adjacent municipalities & Municipalities in same county & Municipalities within 25-mile radius \\
\hline Equal weight & $\begin{array}{c}0.00297 \\
(0.00297)\end{array}$ & & $\begin{array}{c}0.00176 \\
(0.00572)\end{array}$ \\
\hline Population & $\begin{array}{c}0.00177 \\
(0.00256)\end{array}$ & & $\begin{array}{c}0.00327 \\
(0.00561)\end{array}$ \\
\hline Meals tax base & $\begin{array}{c}0.00124 \\
(0.00240)\end{array}$ & & $\begin{array}{c}0.00259 \\
(0.00500)\end{array}$ \\
\hline$\frac{1}{\text { Distance }}$ & & $\begin{array}{c}0.000791 \\
(0.00437)\end{array}$ & $\begin{array}{c}0.00107 \\
(0.00547)\end{array}$ \\
\hline$\frac{\text { Population }}{\text { Distance }}$ & & $\begin{array}{c}0.00103 \\
(0.00425)\end{array}$ & $\begin{array}{r}-0.000377 \\
(0.00537)\end{array}$ \\
\hline$\frac{\text { Meals tax base }}{\text { Distance }}$ & & $\begin{array}{c}0.000812 \\
(0.00396)\end{array}$ & $\begin{array}{r}-0.000475 \\
(0.00491)\end{array}$ \\
\hline
\end{tabular}

Source: Author's calculations.

Notes: ${ }^{*} p<0.10,{ }^{* *} p<0.05,{ }^{* * *} p<.01$.

Standard errors (in parentheses) are clustered at the municipality level.

Coefficients are estimated using the full specification (county fixed effects included).

In the placebo test, towns are assigned the neighbors' adoption percentages corresponding to the town that comes after them alphabetically; for example, Abington is assigned the percentages belonging to Acton. 
Figure 1. Cumulative Percentage of Massachusetts Municipalities Adopting Local-option Meals Tax

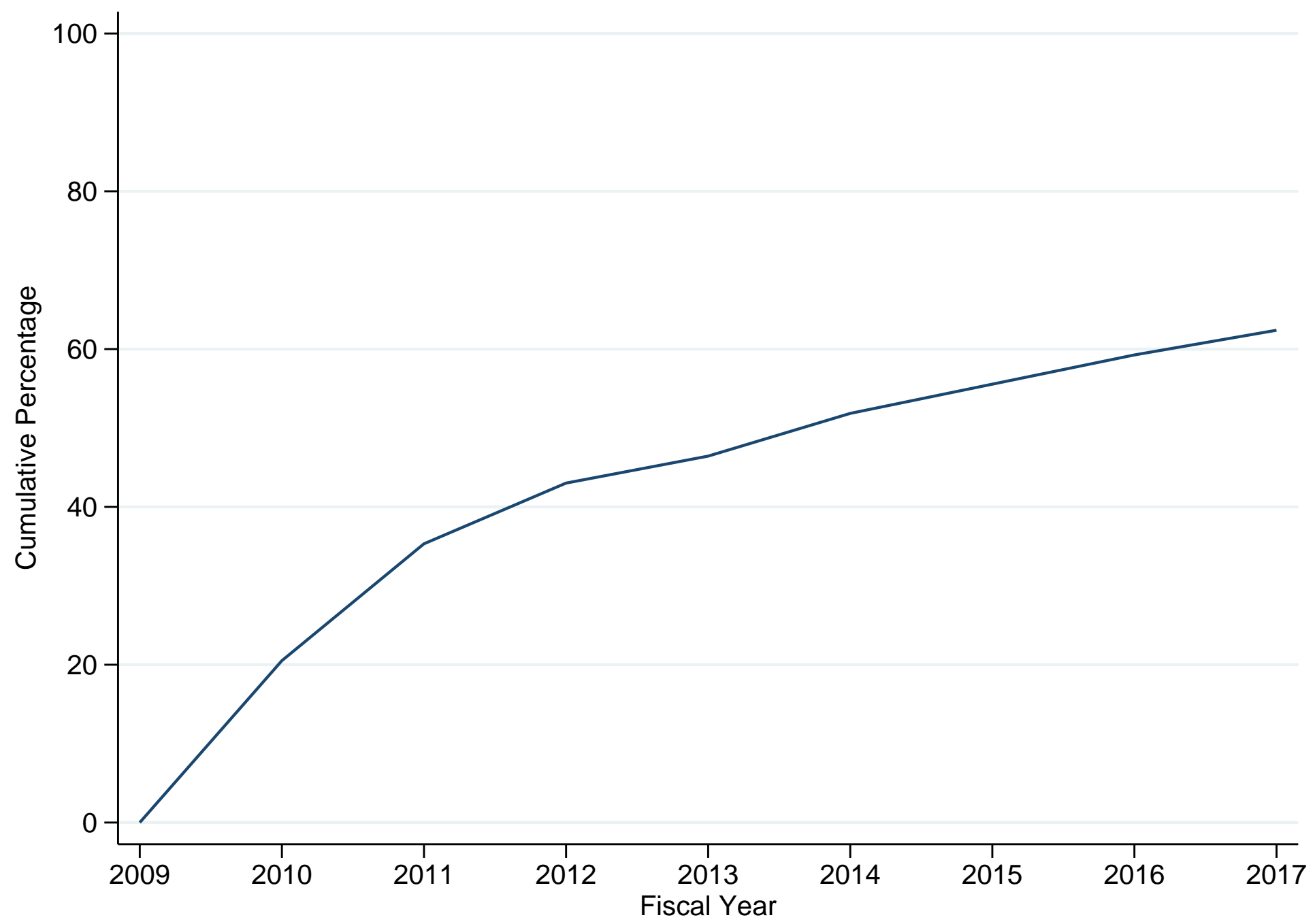

Source: Massachusetts Department of Revenue, Division of Local Services 
Figure 2. Smoothed Hazard Estimate for Adoption of Local-option Meals Tax

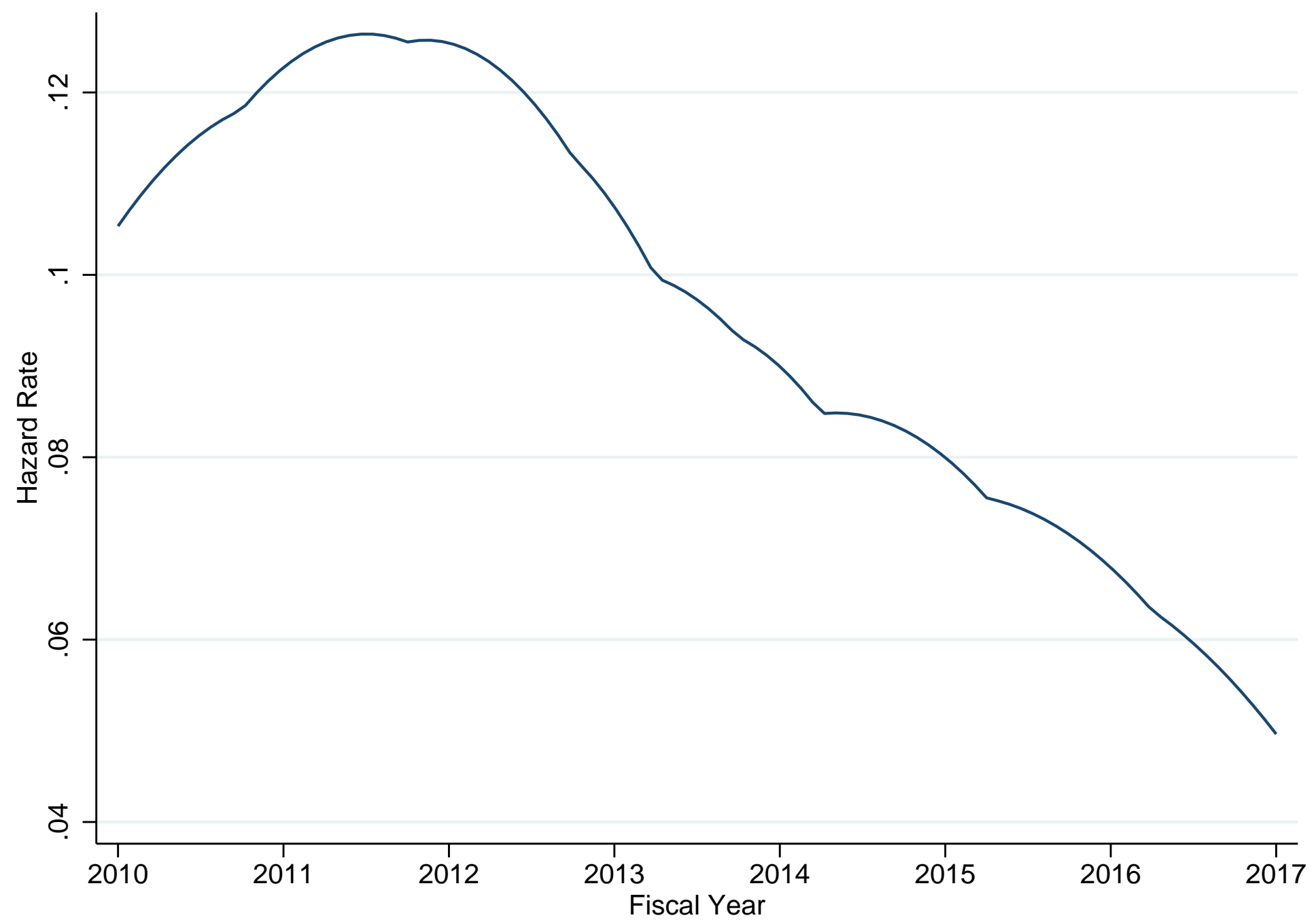

Source: Author's calculations 
Figure 3: Municipalities Adopting Local-option Meals Tax by Given Year

Panel A: FY2010

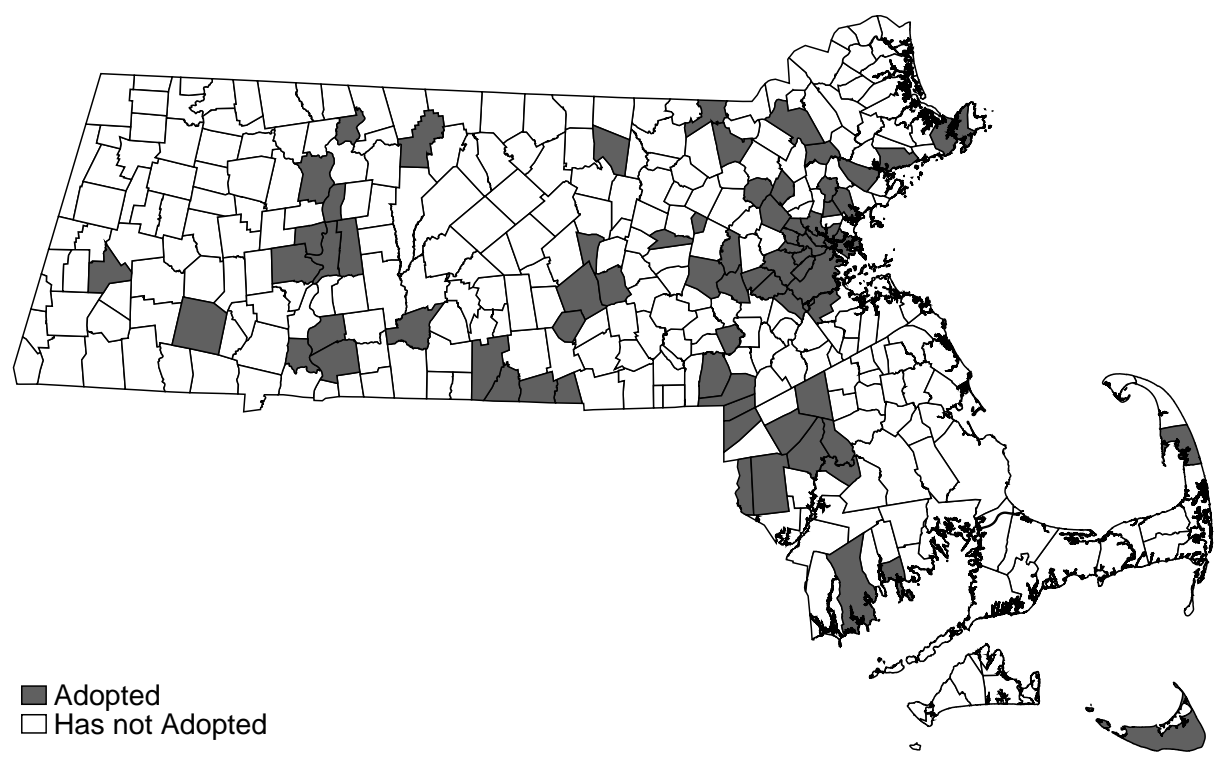

Panel B: FY2013

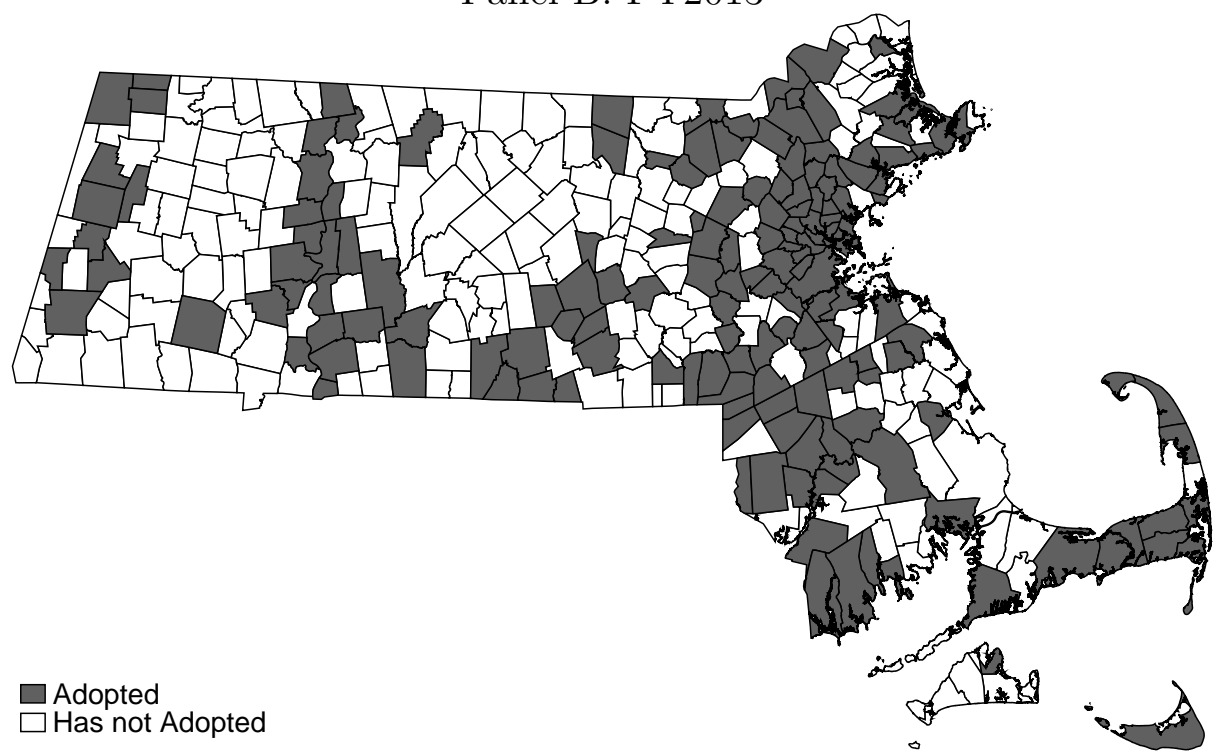

Panel C: FY2017

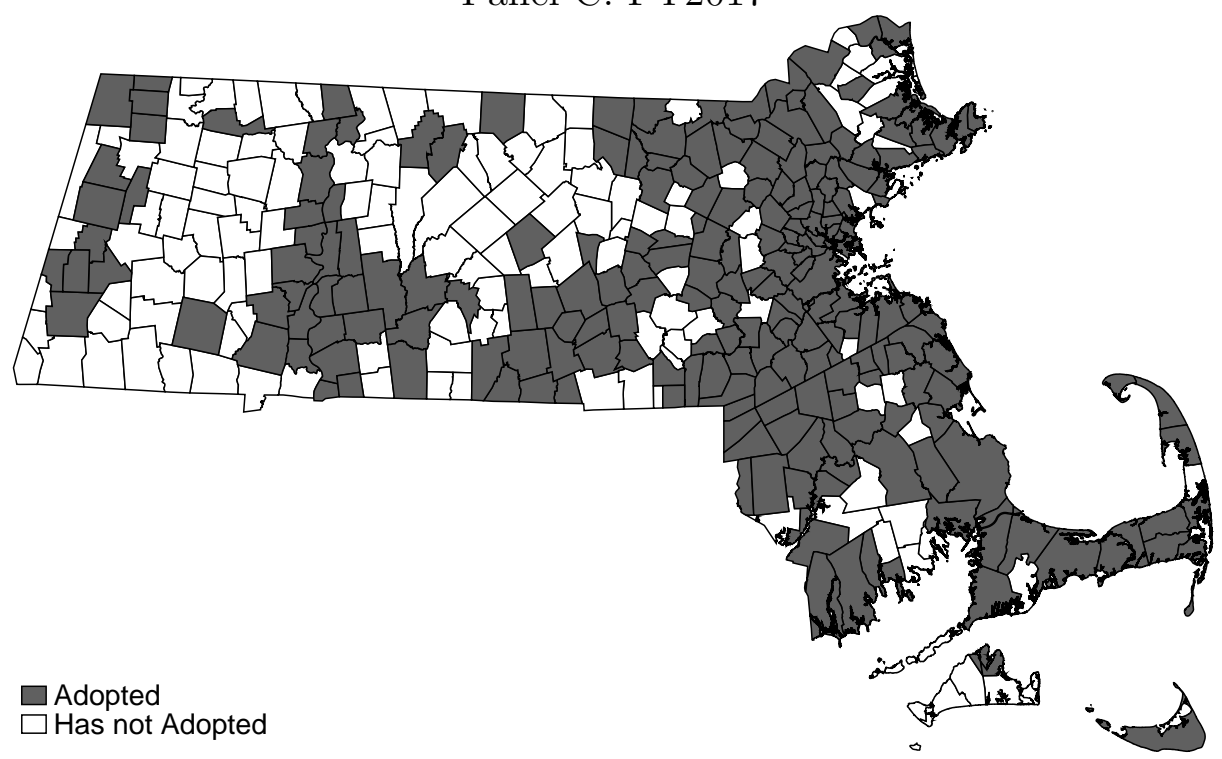

Source: Massachusetts Department of Revenue, Division of Local Services 